\title{
A Study on the Construction of Foreign Language Proficiency Assessment System in Higher Vocational Colleges
}

\author{
Hongxia Zhao \\ Dalian Vocational and Technical College \\ Dalian, China
}

\begin{abstract}
As soon as the concept of National Foreign Language Proficiency Assessment System is put forward, it has brought about a new direction of reform for all levels of foreign language teaching in China. Based on this concept and China's Standards of English Language Abilities implemented on June 1, 2018, this paper analyzes the realistic demands of the construction of the foreign language assessment system in higher vocational colleges and puts forward some thoughts on constructing this system and improving the ability of information-based teaching of in higher vocational colleges so as to provide the necessary reference and basis for the construction of the foreign language evaluation system, the reform of foreign language teaching and the information-based teaching ability of foreign language teachers in higher vocational colleges.
\end{abstract}

Keywords—vocational colleges; foreign language proficiency; assessment system

\section{INTRODUCTION}

In September 2014, China's State Council promulgated the Opinions on Deepening the Reform of the Examination and Enrollment System, which strengthens the Foreign Language Proficiency Assessment System (hereinafter referred to as FLPAS)Construction for the first time. The concept of FLPAS has brought a new direction of reform to foreign language teaching in higher vocational colleges in China. In order to implement the Opinions on Deepening the Reform of the Examination and Enrollment System, the Ministry of Education has determined that the goal of China's FLPAS is to promote the reform of the content and form of the English exam on the basis of the establishment of national foreign language assessment standards. We will achieve the convergence or integration of the National English Proficiency Test and the existing foreign language examinations and initially complete the National English proficiency Test. By 2020, a modern FLPAS with unified standards and diverse functions will be basically established.

On June 1, 2018, China's Standards of English Language Abilities (hereinafter referred to as CSELA) was implemented. This is the first ability standard covering nine levels and three stages of English teaching, English learning and English assessment from primary education to higher education, and it is also an important achievement of the FLPAS in China [1]. Among them, the first and second level roughly corresponds to the primary school level, the third level corresponds to junior middle school, the fourth level corresponds to senior high school, the fifth and sixth grade corresponds to the university, the seventh level corresponds to the English major, and the eighth and ninth level corresponds to the high-end foreign language talents. This is the first ability standard to concerning English teaching, learning and evaluation at all stages of education in China.

As an important part of higher education in China, the research on the evaluation standard of foreign language ability of students in higher vocational colleges should also closely follow the construction of national FLPAS and explore its own evaluation standard of higher vocational college students, promoting the reform of foreign language teaching and improve the quality of foreign language education in higher vocational colleges [2].

\section{THE PRACTICAL SIGNIFICANCE OF THE CONSTRUCTION OF FLPAS IN HIGHER VOCATIONAL COLLEGES}

\section{A. Filling in the Lack of FLPAS in Higher Vocational Education}

Under the framework of national FLPAS, the active construction of higher vocational FLPAS will change the current English teaching and evaluation in China. At present, teachers and researchers in higher vocational colleges do not pay enough attention to the evaluation of foreign language ability, and the pace of construction in foreign language ability evaluation system in higher vocational colleges is slow. The construction of FLPAS in higher vocational colleges will actively promote foreign language teachers to actively carry out teaching reform, update teaching contents and explore evaluation methods characterized by information technology.

This paper aims at improving the foreign language teaching and intercultural communication abilities of higher vocational students and cultivating technical talents who meet the needs of society and enterprises. Only by actively strengthening the research in this area, can we speed up the pace of foreign language teaching reform in higher vocational colleges, improve the effect of foreign

This paper is supported by The 13th Five-year Plan for Educational Science Project of Liaoning -A Research on the Internationalization Path of Higher Vocational Education in Our Province (JG17ZXDWB015) 
language teaching, serve the internationalization of higher vocational colleges and national Belt and Road Initiative.

\section{B. Making up for the Deficiency of study in the construction of FLPAS in Higher Vocational Colleges}

At present, there are some problems in FLPAS in higher vocational education. First, FLPAS in higher vocational education is not clear, and the standard of FLPAS is not unified, which greatly reduces the effectiveness of foreign language proficiency assessment of higher vocational students. Second, according to the national FLPAS and CSELA, how to dock foreign language proficiency assessment in higher vocational education with the corresponding foreign language examination and how to connect different educational stages of education is still a blank of research.

\section{Promoting the Vocational Education Ability of Foreign Language Teachers Supported by Information Technology}

At present, information technology is sweeping all fields of education in our country, changing people's traditional educational concept, teaching methods and teaching modes with each passing day. By 2017 , more than $80 \%$ of higher vocational colleges have reached the national standard of Digital Campus Construction Standard for Vocational Colleges.

Among them, there are 571 vocational colleges with more than 3000 network information access points, $89 \%$ of the campus wireless network construction rate, and 402 colleges and universities have a total management information system data of more than 1000 (GB).This provides a necessary information environment for foreign language teachers in higher vocational colleges to carry out the teaching reform supported by information technology based on CSELA and explore the construction of FLPAS by means of big data and cultivate web-based autonomous learning ability for students [3].

Only through the comprehensive integration of information technology and foreign language evaluation can we really promote the reform of foreign language teaching in higher vocational education, which will usher in a new era of foreign language teaching and predict the new direction of the development of foreign language teaching in higher vocational education in the future .

\section{The CONSTRUCTION OF Foreign LANGUAGE PROFICIENCY ASSESSMENT SYSTEM IN HIGHER VOCATIONAL COLLEGES IN CHINA}

The current foreign language assessment follows the university standard either in concepts or the evaluation models to a certain extent without its own characteristics of foreign language teaching in higher vocational education. Therefore, the construction of FLPAS in higher vocational education needs to innovate the concepts and methods. As an important part of CSELA, foreign language teaching and evaluation in higher vocational colleges should not blindly copy undergraduate practice, but develop an evaluation system that conforms to the characteristics of higher vocational education, constructing FLPAS with a high degree of recognition in the society and accuracy of reflecting the foreign language ability of higher vocational students.

\section{A. An investigation on the Construction of FLPAS in Higher Vocational Colleges}

In order to construct the FLPAS of higher vocational colleges in China, it is necessary to carry out extensive survey on the needs of foreign language assessment and fully understand the level of foreign language ability of higher vocational college students in our country. Among the 1364 higher vocational colleges in China, the number of higher vocational colleges in the eastern part of China is the highest, accounting for $40.10 \%$, followed by the central region for \%and the western region for \%, which reflects an imbalance in the development of higher vocational education in the eastern, central and western regions [4].

In the aspect of foreign language ability, students' English ability also vary in uneven levels, bearing great differences among them. In order to successfully construct the FLPAS of higher vocational colleges, it is necessary to clarify the foreign language examination needs of students in different regions of our country to make clear the purpose, test content, test method, test object, test time, test environment in higher vocational colleges.

At the same time, we should fully draw lessons from the existing foreign language examination trends and social feedback, deeply grasp the goal and significance of higher vocational FLPAS, design the evaluation task and content objectively and pertinently so as to ensure the quality and validity of the test [5]. Only by carrying out investigation and clearly grasping the overall foreign language ability of students in higher vocational colleges can we provide the necessary basic data for the construction of foreign language ability assessment system.

\section{B. Actively Carrying out Teaching Research and Practice based on FLPAS in Higher Vocational Education}

The implementation of CSELA provides standards and guidelines for foreign language teaching in higher vocational colleges in China. Researchers, teachers and managers should actively strengthen the study and research on related contents. Higher vocational colleges should also actively explore a new foreign language teaching model supported by information technology based on IESA.

On the one hand, the integration of information technology and foreign language teaching innovates the teaching model, changes the traditional classroom teaching, enhances the practicality of students' language operation and the initiatives the learning by providing real context. On the other hand, according the language comprehension, language expression, pragmatic competence, language knowledge, translation competence and language usage 
strategies described in the CSELA, higher vocational colleges should actively carry out the reform of teaching modes, the innovation of evaluation methods, the construction of teaching resources such as teaching materials in the courses of Spoken English, English Listening, English Reading, English Writing and so on.

\section{Constructing the FLPAS in Higher Vocational Education with the Cooperation of Many Parties}

Construction of FLPAS in higher vocational education in China is by no means a simple project achieved overnight. It needs the wisdom and cooperation of the Ministry of Education, scientific research institutions and higher vocational colleges by breaking the isolation among them so as to build a communication platform for active participation of various parties.

The Foreign Language Teaching Committee of the Ministry of Education can also provide an academic platform for language teaching and evaluation by holding academic conferences and scientific research projects, sharing the research results of language assessments with teachers and researchers in high schools, higher vocational colleges, universities so as to facilitate the smooth docking of different stages of foreign language education.

\section{Constructing the Evaluation System of FLPAS in Higher Vocational Education}

Construction of FLPAS should be subordinated to the theoretical basis and scientific judgment of foreign language education and testing. The success of FLPAS in higher vocational colleges will have huge influence on the comprehensive quality of students, the professional growth of teachers, the reputation of the colleges and so on. It not only affects the employment competitiveness of students in higher vocational colleges, but also affects the strategic layout of national language ability construction in our country. A complete and efficient evaluation system of FLPAS will be able to dynamically evaluate and supervise the practical effect of foreign language teaching and evaluation in higher vocational education and further improve the FLPAS in higher vocational education [6].

\section{THE WAYS TO IMPROVE TEACHERS' INFORMATION TECHNOLOGY TEACHING ABILITY BASES ON FLPAS IN HIGHER VOCATIONAL EDUCATION}

One of the key factors in the construction of FLPAS in higher vocational colleges is English teachers. They undertake the important tasks of actively exploring foreign language teaching based on CSELA, guiding students to form autonomous learning ability and applying the results of foreign language assessment to improve foreign language teaching. The improvement of information technology teaching abilities of higher vocational colleges based on CSELA will become an important factor in constructing FLPAS and using the evaluation results to improve foreign language teaching
A. Government Policy's Guidance to Promote the Design and Implementation of Relevant Training Programs

In August 2017, the Ministry of Education issued the Guidance on Further Promoting the Informatization Development of Vocational Education, which pointed out the road and development direction for the information technology teaching in higher vocational colleges. And the improvement of information-based teaching ability of foreign language teachers in higher vocational colleges based on CSELA is a dynamic development process. The government and colleges should improve teachers' information-based teaching ability by providing effective policies and excellent environment. At the same time, teachers in higher vocational colleges should also give full play to their initiative and make an in-depth study on the practice and evaluation of FLPAS based on CSELA.

\section{B. Strengthening the Resource Construction of Foreign Language Teaching in Higher Vocational Colleges by Optimizing the School Mechanism}

The core of the informatization of higher vocational foreign language education lies in the construction of resources, especially the construction and application of practical teaching resources. At present, there is a lack of high-quality English training resources, which can't meet the needs of foreign language practical teaching.

In addition, the higher vocational colleges should establish an effective incentive and evaluation mechanism to encourage and guide teachers to participate in all kinds of information teaching competitions at all levels, promoting the construction of FLPAS with the information-based teaching, which will be conducive to cultivating technical and skilled personnel recognized by the society and welcomed by enterprises.

\section{Teachers' Self-drive to Improve the Development of Information-based Teaching Ability}

Most of the foreign language teachers in higher vocational colleges are women, whose information literacy is generally not high and the desire to learn and use information technology is not strong. On the contrary, Millennium babies have entered the higher vocational campuses, who were born in the era of intelligence and have high information literacy. In this way, from the aspect of learning, it puts forward new requirements for the information-based teaching of foreign languages in higher vocational colleges.

Teachers in higher vocational colleges should be fully aware of the necessity of integrating information technology with foreign language teaching. We should establish a correct concept of information-based teaching, actively explore information technology means such as big data to improve teaching methods, guide students to study independently and then improve the effect of foreign language teaching. 


\section{SUMMARY}

The construction of FLPAS in higher vocational colleges will help higher vocational colleges to correctly deal with the relationship among foreign language teaching, students' autonomous learning, evaluation and the use of evaluation results. The teaching research and practice based on CSELA supported by information technology will realize the new type of "teaching" and "learning", change the traditional foreign language evaluation structure and contribute the informatization and internationalization of higher vocational education so as to cultivate the technical and skilled talents for the national Belt and Road Initiative strategy.

\section{REFERENCES}

[1] China's Standards of English Language Abilities, National Working Committee on Spoken and Written Languages, Higher Education Press, 2018,pp 2-3.

[2] Li Yulong, Gu Xiangdong. A Summary of Research on China's Standards of English Language Abilities, Foreign Language Translation, 2019, Vol.3, pp.85-86

[3] Max Institute. Annual Report on the Quality of Higher Vocational Education in China 2017], Higher Education Press, 2017, pp. 27-28.

[4] Chen Gongmeng. China Vocational Education Yearbook (2017), Economic Management Press, 2017, pp. 48-49.

[5] Lu Shenglu. The Realization Path and Reflection on the Construction of Foreign Language Proficiency Assessment System in China, Global Education Prospect, 2015 vol. 5, pp. 119-121.

[6] Pang Yunling, Chen Juan. College English Teaching Reform in the context of Informatization, China Textile Publishing House, 2017, pp.141-142. 